\title{
RBM14 wt Allele
}

National Cancer Institute

\section{Source}

National Cancer Institute. RBM14 wt Allele. NCI Thesaurus. Code C114449.

Human RBM14 wild-type allele is located in the vicinity of 11 q13.2 and is approximately

$22 \mathrm{~kb}$ in length. This allele, which encodes RNA-binding protein 14, is involved in the modulation of gene transcription. 